\title{
Dorota Skotarczak
}

Instytut Historii Uniwersytetu Adama Mickiewicza

\section{Kilka uwag o historii wizualnej}

Zarys treści: Historia wizualna to subdyscyplina historii zajmująca się badaniem przedstawień (audio)wizualnych związanych z przeszłością, o charakterze artystycznym (malarstwo, fotografia, film i in.). Historia wizualna wychodzi z założenia, że obserwowany współcześnie wzrost znaczenia form wizualnych zmusza naukę historyczną do reorientacji. Wskazuje więc na potrzebę wykorzystywania jako źródeł także fotografii czy filmu. Interesuje się też edukacją historyczną i wykorzystaniem wiedzy historycznej w celach popularyzatorskich bądź hobbistycznych, za pomocą środków audiowizualnych. Reorientacja ta inicjuje refleksję zmierzającą do wypracowania teoretycznych i praktycznych rozwiązań.

The outline content: Visual history is a subdiscipline of history with the goal of studying the visual representations of the past as found in photography, film, art, and so on. It is based on the assumptions that the increasing role of visual representations in modern culture has made it necessary for historiography to reorient its approach to a number of issues. Visual history views film and photography as legitimate historical sources. It also deals with the use of audiovisual means in teaching and popularising history. Historiography's attempt to redefine its role initiates a discussion that makes possible the elaboration of ways of coping with the challenges in question.

Słowa kluczowe: historia, historia wizualna, film jako źródło historyczne

Keywords: history, visual history, film as a historical source

Historyk ślęczący w archiwum nad pożółkłymi dokumentami należy do stereotypu profesji. Ale badacz dziejów - zwykle nowszych - oglądający fotografie czy filmy i na ich podstawie wyrabiający sobie pogląd na temat przeszłości to jakby nowa jego rola. Tak samo historyk upowszechniający wyniki swoich lub cudzych badań za pomocą filmu. Również organizator różnego rodzaju widowisk historycznych. Historia uprawiana przez nich wymaga innego warsztatu, którego organizacja z pewnością nie jest sprawą łatwą.

Nie od dziś słyszy się o zmianach zachodzących w naszej cywilizacji, polegających na coraz częstszej komunikacji za pośrednictwem środków wizualnych bądź audiowizualnych. Zjawisko to zdaje się być dobrze znane, także dzięki poważnym badaniom prowadzonym nad różnymi jego aspektami. Tutaj pragnę zwrócić uwagę 
na to, że owe zmiany wymuszają pewną reorientację ze strony nauk humanistycznych. Przedstawiciele poszczególnych dyscyplin muszą rozwiązywać coraz więcej problemów, które nie ograniczają się li tylko do kartki papieru z tekstem, odręcznie zapisanym czy zadrukowanym, lecz związane są z jakimiś obrazami, nierzadko ruchomymi i powiązanymi z dźwiękiem.

Wspomniana reorientacja dotyczy także nauk historycznych. Historycy w swej pracy coraz częściej z różnych przyczyn mają do czynienia z materiałami wizualnymi i audiowizualnymi, co nolens volens sprawia, że ich dyscyplina nie jest taka sama. Nie znaczy to jednak, że musi być naruszona jej istota. Potrzebna staje się zatem pogłębiona refleksja na temat pracy historyka nad źródłami wizualnymi i audiowizualnymi czy posiłkowania się przezeń obrazami. Swego czasu zaproponowałam ujęcie tej refleksji w jakąś formę uporządkowaną - historię wizualną, którą definiuję w sposób następujący: „Historia wizualna to zorientowana multi-dyscyplinarnie subdyscyplina badawcza zajmująca się analizą przedstawień (audio)wizualnych w kontekście historycznym. W tym rozumieniu historia wizualna obejmuje swym zasięgiem wszystkie te sfery, które występują na styku historii/ historiografii, fotografii, filmu, sztuk plastycznych, nowych mediów i wszelkiej wizualizacji przeszłości i wiedzy historycznej. Do jej zadań należy zaś z jednej strony - wskazanie na rolę, jaką przedstawienia (audio)wizualne odgrywają $\mathrm{w}$ tworzeniu przedstawień historycznych (wyobrażeń o przeszłości), stając się swoistą alternatywą dla akademickiej historiografii. A z drugiej - wskazanie na metody badawcze przydatne do analizy audiowizualnych reprezentacji przeszłości jako relatywnie nowych i równorzędnych wobec pisanej historii form refleksji o przeszłości oraz źródeł historycznych wymagających od historyka nowych umiejętności w zakresie krytyki i hermeneutyki przekazów medialnych"1.

Dziedzina nazwana przeze mnie historią wizualną, jak się wydaje, czerpie $\mathrm{w}$ pewnym stopniu z myśli amerykańskiej. Z tamtego kierunku przyszło rozpowszechnione dziś określenie „zwrot wizualny”, nie mówiąc o dokonaniach Haydena White'a, Roberta Rosenstone’a i innych historyków. Jednak refleksja pod szyldem historii wizualnej wcześniej w naszym kraju nawiązywała do prac Europejczyków. Mam na myśli prace Lotty Eisner, Siegfrieda Kracauera - Niemców, choć niekoniecznie mieszkających w Niemczech, a także Francuzów - Marca Ferro i Edgara Morina. Europejskie inspiracje sprzed kilkudziesięciu lat pobudzały do rozważań nad filmem i ewentualnie fotografią. Późniejsze amerykańskie, koncentrujące się także na nowych nośnikami informacji, odpowiednio rozszerzyły zakres zainteresowań.

${ }^{1}$ Definicję mojego rozumienia historii wizualnej przedstawiłam już w swoim artykule Projekt historii wizualnej, „Slavia Occidentalis” 2011, nr 68, s. 175-176. Wstępnie starałam się zdefiniować historię wizualną w artykule Historia wizualna. Założenia teoretyczne i zakres badawczy, w: Historia w kulturze wspótczesnej. Niekonwencjonalne podejście do przeszłości, red. P. Witek, M. Mazur, E. Solska, Lublin 2011, s. 87-94. 
Podkreślić trzeba, że polskie rozważania, które przybierają dziś postać historii wizualnej, nie mają charakteru odtwórczego, nie ograniczają się do przyswojenia myśli wyrażonych w pracach obcych. Wynika to nie tylko $\mathrm{z}$ tego, że prace Bolesława Matuszewskiego ${ }^{2} \mathrm{z}$ końca XIX w. właściwie inicjują wszelką dyskusję na temat wizualnych (filmowych) źródeł historycznych. Także po Matuszewskim formułowano ciekawe spostrzeżenia, a nawet teorie.

Z przytoczonej definicji historii wizualnej wynika, że zadaniem tej subdyscypliny jest odpowiedź na pytanie o znaczenie materiałów (audio)wizualnych $\mathrm{w}$ warsztacie historyka, o rolę, jaką pełnią one w kreowaniu wyobrażeń o przeszłości i ich potencjalną wartość jako źródeł historycznych. Pod pojęciem owych materiałów (audio)wizualnych rozumieć należy nie tylko źródła, ale i wszelkie przedstawienia przeszłości wykreowane za pomocą obrazów, niezależnie od tego, czy są one ruchome i wyposażone w dźwięk, czy też nie.

W pierwszej kolejności chciałabym się zastanowić, jakie mogą mieć w ogóle zastosowanie materiały audiowizualne. Dwa podstawowe zastosowania, które nasuwają się niejako samoistnie, to użycie ich w charakterze źródeł historycznych oraz w dydaktyce historii. Wydaje się, że oba te zastosowania nie budzą już większych wątpliwości. Inną sprawą jest wypracowanie odpowiednich metod badawczych ${ }^{3}$. Sądzę jednak, że historyk nie powinien ograniczać się do tych dwóch tylko, wymienionych wyżej, zastosowań.

Ponieważ współcześnie właśnie na podstawie materiałów audiowizualnych kształtuje się wyobrażenie o tym „jak to było", nauki historyczne, a szczególnie historia wizualna zyskuje kolejne pole dla swej aktywności. Chodzi tu o ustosunkowanie się do wszelkich kwestii dotyczących przeszłości, w które uwikłane są obrazy.

Historycy dotąd tą tematyką zajmowali się w stosunkowo niewielkim stopniu. Nierzadko ich zainteresowanie ma charakter doraźny. Tak jest np. gdy trzeba

${ }^{2}$ Zob. wydane sto lat od pierwodruku: B. Matuszewski, Nowe źródło historii. Ożywiona fotografia: czym jest, czym być powinna, Warszawa 1995.

${ }^{3} \mathrm{Na}$ temat zastosowania materiałów audiowizualnych jako źródeł pisałam wielokrotnie; zob. np. D. Skotarczak, Obraz społeczeństwa PRL w komedii filmowej, Poznań 2004; taż, Film fabularny jako źródło do badań historii społecznej PRL, w: Dokument filmowy i telewizyjny, red. M. Szczurowski, Torun 2004, s. 156-169; taż, Wśród filmowych źródeł do historii Polski Ludowej, „Porównania. Czasopismo poświęcone zagadnieniom komparatystyki literackiej oraz studiom interdyscyplinarnym" 2010, nr 7, s. 141-150; taż, Historia wizualna, Poznań 2012, 2013, rozdz. III, s. 108-154; zob. też W. Olejniczak, Film fabularny jako źródło historyczne, w: Media audiowizualne $w$ warsztacie historyka, red. D. Skotarczak, Poznań 2008, s. 25-52. Na temat filmu w dydaktyce historii zob. m.in. D. Skotarczak, Kino PRL-u w materiałach dydaktycznych MEN, w: Uwikłania historiografii. Między ideologizacją dziejów a obiektywizmem poznawczym, red. T. Błaszczyk, K. Brzechczyn, D. Ciunajcis, M. Kierzkowski, Poznań 2011 (Studia i Materiały Poznańskiego IPN, 18), s. 177-184. 
wypowiedzieć się na temat kontrowersyjnych fotografii (np. zamieszczonych w Krwawym żniwie Jana Tomasza Grossa). Ale wydaje się, że przekazy audiowizualne powinny stać się przedmiotem szerszego zainteresowania, choćby ze względu na siłę ich oddziaływania.

Poza tym nie mają one charakteru neutralnego i krytyczne spojrzenie profesjonalnego krytyka mogłoby przynieść wiele ciekawych konstatacji. Przekazy audiowizualne dotyczące historii powinny zatem stać się przedmiotem krytycznej oceny. Dyskusje naukowe nie powinny ograniczać się do polemiki na temat publikacji historycznych, ale objąć swoim zasięgiem filmy historyczne, programy dokumentalne, widowiska telewizyjne, programy informacyjne, inscenizacje o tematyce historycznej. Okazać się wówczas może, że owe materiały audiowizualne są nie tylko niezmiernie bogate, lecz zawierają też zaskakujące interpretacje wydarzeń historycznych ${ }^{4}$.

Materiały audiowizualne, a więc filmy, dokumenty filmowe, spektakle telewizyjne, krótkie filmy o charakterze informacyjnym, ale także różnego rodzaju okazjonalne wizualizacje historii, elementy audiowizualne w muzeach historycznych - wszystkie one mogą być (choć nie zawsze są) elementem polityki historycznej danego państwa. Kształtowane są wówczas w sposób świadomy, aby uzyskać określone cele propagandowe. W różnych okresach cele te mogą być zupełnie odmienne, a nawet ze sobą sprzeczne. Zależeć mogą od doraźnie prowadzonej polityki lub realizować zamierzenia długofalowe. Mogą dotyczyć historii własnej lub dziejów innych krajów.

Treści historyczne zawarte w materiałach audiowizualnych są $\mathrm{w}$ jakiś sposób odzwierciedleniem wiedzy o przeszłości, świadomości historycznej charakterystycznej dla danego okresu. Twórcy filmów, programów itp. są członkami społeczeństwa, dla którego tworzą, często nie zajmują się historią profesjonalnie, a nawet jeśli, to liczyć się muszą z tzw. przeciętnymi gustami odbiorców. A więc treści historyczne w materiałach audiowizualnych $\mathrm{z}$ jednej strony kształtują naszą świadomość, a z drugiej są jej odzwierciedleniem. Mogą więc stanowić materiał do badań świadomości zbiorowej.

Zawartość treściowa zależy też od poglądów twórców danych przekazów audiowizualnych - poszczególnych osób bądź określonych środowisk twórczych, dziennikarskich itp. Również z tego punktu widzenia dostarczać mogą ciekawych informacji. Poza tym przekazy audiowizualne, zarówno filmy, jak i spektakle, dokumenty, programy informacyjne w jakiejś mierze, o czym już wspomniałam, odzwierciedlają świadomość historyczną epoki. Ale jednocześnie dostosowane

${ }^{4}$ Postulat zainteresowania się taką tematyką jest zresztą zrealizowany, choć w niewielkim zakresie. Jednak powstałe teksty potwierdzają moją tezę, że materiały audiowizualne o treściach historycznych są niezmiernie ciekawym przedmiotem analizy; zob. np. artykuły P. Witka czy M. Mazura o Teatrze Telewizji, zawarte w pracy Historia w kulturze współczesnej... 
są do wrażliwości odbiorcy. Należy domniemywać, że gdyby dzisiaj w filmie fabularnym starano się odtworzyć warunki higieniczne ${ }^{5}$, kwestie dotyczące leczenia itp., to wywołałoby to szok dużej części publiczności. Dostosowuje się więc obraz przeszłości do nie tylko gustów, ale też możliwości odbiorczych dzisiejszego widza.

Nie można też przeoczyć treści zawartych $\mathrm{w}$ Internecie. Ze zrozumiałych względów są one nie do opanowania w całości. Sprawę utrudnia też ich płynność (nie bez powodu robiąc przypis do stron internetowych, podajemy datę wejścia). Niemniej jednak stanowią one dziś materiał, którego nie można pominąć. Obok rozwiniętych i uznanych portali, jak choćby histmag czy historiaimedia, istnieją mniej znane, będące przejawem zainteresowań społecznych historią, powstałe spontanicznie, których celem jest rozwój własnego hobby. Niekiedy zawierają one informacje nieprawdziwe, a w każdym razie kontrowersyjne. Są jednak dowodem na potrzebę wiedzy historycznej i wskazują obszary szczególnie ciekawe z punktu widzenia odbiorcy. Sądzę, że nawet podstawowe badania o charakterze statystycznym mogłyby doprowadzić do ciekawych wniosków.

Zwróćmy uwagę, że we wszystkich powyższych punktach mówiliśmy w gruncie rzeczy o pewnym konstruowaniu wiedzy historycznej. Warto tu odwołać się do historyków reprezentujących koncepcje narratywistyczne i odwołujących się do konstruktywizmu. Mam tu na myśli z polskich badaczy głównie Piotra Witka, który poświęcił filmowi cytowane tu opracowania. Przy czym jego poglądy można rozszerzyć na wszystkie przekazy o charakterze audiowizualnym.

Takie przekazy są dziś zasadniczym nośnikiem treści historycznych, lecz ulegają one świadomemu bądź nieświadomemu kształtowaniu. Świadomemu, gdy chodzi o politykę historyczną, niekoniecznie świadomemu w innych przypadkach. Historia podlega tu innym operacjom intelektualnym, bywa konstruowana na nowo, zależnie od zapotrzebowań, zainteresowań, wiedzy i umiejętności osób nią się zajmujących. Nie musi koniecznie być budowana w jakimś określonym celu. Może być efektem chwilowej mody, której przyczyn niekiedy nie sposób ustalić, czy też zainteresowań określonym tematem. Owa moda i zainteresowania - nie mówiąc już o polityce historycznej - ulegają zmianom i fluktuacjom ${ }^{6}$.

Można rzec, że właśnie w dobie kultury audiowizualnej historia powraca. Wszelka krytyka historii odbywa się poprzez odsyłanie do niej, wszelkie „przeróbki” zdają się komentarzem do tego, co było już wcześniej. Istnieją specjalne kanały telewizyjne poświęcone historii, które w dużej mierze zajmują się przypominaniem starych programów. Przykładem mogą być kanały Kino Polska czy

${ }^{5}$ Które współczesnym historykom nie są obojętne; zob. np. K. Ashenburg, Historia brudu, tłum. A. Górska, Warszawa 2010.

${ }^{6}$ Warto tu też przypomnieć klasyczne opracowanie: J. Szacki, Tradycja. Przegląd problematyki, Warszawa 1973. 
TVP Historia. Również TVP Kultura pokazuje sporo programów rozrywkowych, publicystycznych, dokumentalnych zrealizowanych przed wielu laty. Program tych kanałów zresztą sam w sobie mógłby stać się przedmiotem odrębnych opracowań. Oto Kino Polska, które z założenia przypomina starą rodzimą produkcję i promuje nowości, nie stroni od filmów zrealizowanych w krajach tzw. demokracji ludowej, nie wyłączając ZSRR. Jest to zjawisko niezmiernie interesujące także z punktu widzenia naszych tu zainteresowań. Cóż bowiem może to oznaczać - że dorobek telewizji owych „demoludów” traktuje się łącznie? Historia PRL zlewa się z historią innych krajów, należących wszakże do tego samego bloku politycznego, aczkolwiek znajdujących się w sytuacji zgoła odmiennej, bo przecież położenie Polski i Czechosłowacji było jednak inne niż Związku Radzieckiego. A może jest to uleganie tęsknocie ze strony odbiorców, którzy mają ochotę oglądać nie tylko stare polskie filmy, ale także to, co oglądali przed laty w telewizji przed rokiem 1989? W takim wypadku Kino Polska zamienia się częściowo w kanał przypominający to, co w Telewizji Polskiej pokazywano z dorobku telewizji sojuszniczych państw przed tym przełomowym rokiem ${ }^{7}$. Na zagadnienie to można patrzeć rozmaicie - jako na metodę konstruowania określonej świadomości historycznej, uleganie modzie na popkulturę sprzed 1989 r., banalne „zapychanie” programu, misję przypominania programów, których gdzie indziej nie sposób zobaczyć, choć wzmiankowane seriale są już udostępniane na DVD.

Z kolei sięgając choćby do oferty wspomnianych wyżej stacji telewizyjnych, można stwierdzić, $w$ jak różny sposób kreowano wizje przeszłości naszego kraju. Rzecz jest powszechnie wiadoma i zwrócenie na nią uwagi może wydać się niezbyt odkrywcze. Ale pamiętajmy, że brak szczegółowych opracowań tego zagadnienia, choć z pewnością jest ono nader frapujące. Warto by się zastanowić np. nad obrazem II wojny światowej w filmach poszczególnych okresów aż do dnia dzisiejszego. Bardzo pouczająca byłaby już próba odpowiedzi na zupełnie podstawowe pytania: jakie wojska, w jakim okresie były eksponowane?, jakie grupy ludności i które tereny pokazywano?, czy mamy do czynienia $\mathrm{z}$ heroizacją, czy raczej kieruje się uwagę na słabości ludzkiej natury i okropności wojny? Wyjaśnienie tych wszystkich kwestii może ukazać lansowaną interpretację historii, której twórcy filmów świadomie lub nieświadomie ulegli.

Interesujące byłoby również - o czym już wspomniałam - przyjrzenie się nieprofesjonalnym przekazom dotyczącym historii. Można je znaleźć głównie w Internecie. Przejawiają się w nich rozmaite aspekty obecnej świadomości historycznej i pasji historycznych. Rzecz jasna, pamiętać tu trzeba, że do portali historycznych zaglądają osoby już interesujące się historią, a więc posiadające jakąś wiedzę. Prócz portali historycznych zajmującym przedmiotem badań mogą być

${ }^{7}$ Chcę w tym miejscu podkreślić, że nie wdaję się tu w ocenę takiego, a nie innego doboru programów w kanale Kino Polska. Problem ten mnie w ogóle tutaj nie interesuje. 
te strony internetowe, które nie są nakierowane co do swej istoty na historię, ale gdzie pojawia się ona okazjonalnie. Mam tu na myśli choćby niezmiernie popularny portal YouTube. Jednym z jej przebojów było nagranie szwedzkiej grupy heavymetalowej Sabaton pt. 40:1, poświęcone polskim żołnierzom walczącym podczas kampanii 1939 r. w bitwie pod Wizną. Nagranie Sabatonu obejrzało kilkaset tysięcy osób, wielu z nich utwór ten skomentowało. Już same te komentarze dają pewną wiedzę o poglądach i postawach Polaków. I chociaż nie można ich uznać za absolutnie wiarygodne i miarodajne, to przecież trudno ich nie dostrzegać.

Inną kwestią jest sposób mówienia o historii we współczesnych programach informacyjnych. Mamy tu do czynienia również z pewną kreacją/konstrukcją historii, co w jakiś sposób ma związek z polityką historyczną. Lub też może wobec tej polityki pozostawać w opozycji. Jest to zagadnienie z pogranicza historii i nauk politycznych, aczkolwiek pozostaje w sferze zainteresowań nauk historycznych. Zresztą dziennikarze, prezenterzy telewizyjni również są członkami społeczeństwa, należą do określonych grup środowiskowych, których poglądy, mniej czy bardziej świadomie, przejmują. Ulegają też modom, rozlicznym tendencjom i wpływom. W dodatku przekaz telewizyjny ma swoją specyfikę, która narzuca pewien sposób wypowiedzi - zwykle jest on skrótowy i uproszczony. To zaś sprzyja prezentowaniu myślenia prostymi schematami i powstawaniu stereotypów. Wydaje się więc, że warto zainteresować się także tym zagadnieniem.

Materiały audiowizualne można wykorzystać także jako świadectwo rozwoju techniki. Otóż rozwój sposobu przekazywania informacji, wiedzy, rozwój sztuk audiowizualnych jest odzwierciedleniem postępowych przemian w zakresie kultury technicznej danej epoki. Taśma filmowa, fotografia, zapis cyfrowy, poziom digitalizacji materiałów archiwalnych - wszystko to jest rodzajem źródła dla historii techniki.

I jeszcze jeden, ostatni już sposób wykorzystania materiałów (audio)wizualnych, kojarzący się z omówionym poprzednio. Wydaje mi się jednak, że warto go odnotować oddzielnie. Nie jest to zresztą zjawisko nieopisane, polegające na dominacji jednego sposobu komunikacji w danej epoce. Przejście od kultury słowa pisanego do kultury audiowizualnej, które można obecnie obserwować, tak jak wcześniej pojawienie się druku, a jeszcze wcześniej słowa pisanego, powoduje głębokie zmiany cywilizacyjne ${ }^{8}$. Tym przemianom winna towarzyszyć nieustanna refleksja, która zresztą ma miejsce, chociaż zdaje się ona domeną medioznawców. Ale nie powinni się od niej uchylać również historycy.

8 Są badacze, którzy uważają, że wynalezienie słowa pisanego było wydarzeniem najdonioślejszym w historii i całkowicie odmieniło rozwój cywilizacji; zob. np.: W. Ong, Pismo a struktura świadomości, tłum. M. Pęczak, w: Wiedza o kulturze, cz. 2: Słowo w kulturze. Zagadnienia i wybór tekstów, oprac. M. Boni, G. Godlewski, A. Mencwel, Warszawa 1991, s. 127-144. Inni uczeni generalnie łączą rozwój cywilizacji ze sposobem komunikowania się; zob. np. H. Innis, Empire and Communication, Oxford 1950. 
Wymieniłam kilka sposobów podejścia do materiałów audiowizualnych. Podkreślić jednak należy, że nie muszą one występować rozłącznie. Mogą one być jednocześnie potraktowane jako źródło historyczne, materiał dydaktyczny czy element do badań świadomości historycznej swojej epoki. Zresztą układów może być więcej i nie ma tu żadnych ograniczeń.

Zakres badawczy historii wizualnej powinien być szeroki i obejmować swym zasięgiem wszystkie te sfery, które występują na styku historii, fotografii, filmu, sztuk plastycznych, mediów audiowizualnych oraz wszelkiej wizualizacji historii. Mam świadomość, że wielu badaczy zakres historii wizualnej ogranicza właśnie do kwestii zamieszczania tekstów o charakterze historycznym w Internecie czy wykorzystania komputera dla uprawiania nauki historycznej, prowadzenia historycznych debat czy historycznej edukacji ${ }^{9}$. Przy tym termin „visual history” niekiedy bywa używany zamiennie z „digital history”. Jeśli zaś wejdziemy na strony internetowe wielkich księgarni (np. Amazon, AbeBooks, Alibris, Burns \& Noble) i wpiszemy termin „visual history” to wcale nie zostaną nam zaoferowane książki Roberta Rosenstone’a bądź Roberta B. Toplina, lecz opracowania będące ilustrowaną historią antyku lub Indii. A jednocześnie historycy, zajmując się - także w Polsce zagadnieniem archiwizacji materiałów wizualnych i audiowizualnych, możliwością wykorzystania fotografii i filmu jako źródła historycznego, ale także najnowszymi mediami jako nośnikami wiedzy historycznej, wcale nie używają w odniesieniu do swych badań terminu „historia wizualna”. To wszystko zdaje się dowodzić, że oprócz przedstawionej powyżej definicji historii wizualnej należy koniecznie też określić, jakie dziedziny i jaki obszar badawczy powinna ona obejmować.

Pragnę zatem wskazać na kilka obszarów tematycznych, które, jak sądzę, w jakiejś mierze już składają się na zakres badawczy tej subdyscypliny. Spodziewam się, że można wskazać inne bądź te zaproponowane uporządkować zupełnie inaczej.

Przede wszystkim więc zająć należałoby się kwestią archiwizacji i digitalizacji materiałów wizualnych i audiowizualnych. Zagadnienie to zresztą budzi - co trzeba podkreślić - żywe zainteresowanie polskich archiwistów ${ }^{10}$.

${ }^{9}$ Można tu wskazać na znaną pracę: O.V. Burton, American Digital History, „Social Science Computer Review" 25, 2005, nr 2, s. 206-220.

${ }_{10}$ Zob. np.: H. Karczowa, Rozwój form kancelaryjnych i współczesne rodzaje dokumentów archiwalnych. Dokumentacja wizualna i audialna (fotografia, film, nagrania), Torun 1979; E. Podgórska, Archiwizacja fotografii, w: Poradnik dla archiwisty instytucji polskich na obczyźnie, red. J. Krochmal, Warszawa 2006, s. 73-84; I. Mamczak-Gadkowska, Fotografie i filmy w archiwach, w: Media audiowizualne..., s. 89-105; W.K. Roman, Naukowa informacja archiwalna o materiałach audiowizualnych i jej rola $w$ badaniach historycznych, w: tamże, s. 107-121; Dokument filmowy i telewizyjny..., cz. 2: „Dokument filmowy i telewizyjny. Problem archiwizowania” zawiera artykuły W.K. Roman, P. Duseka, Z. Adamkiewicza, K. Schmidta, R. Galuby, A. Kuleckiej, T. Matuszaka, E. Bimler-Mackiewicz, A. Srebrakowskiego, K. Kawczyńskiej, H. Robótki. 
Następnym zjawiskiem, na które trzeba tu zwrócić uwagę, są rozmaite multimedialne formy wystawiennicze, dla których $\mathrm{w}$ jakiejś mierze prekursorem jest szwedzkie muzealnictwo etnograficzne ${ }^{11}$. W miejsce tradycyjnych budynków muzealnych z obszernymi salami, mnóstwem eksponatów ustawionych w gablotach i wyposażonych w stosowne objaśnienia pojawia się tzw. muzeum multimedialne. To ostatnie różni się od tradycyjnego niekiedy także architektoniczne. Przykładem może być choćby bardzo popularne Muzeum Powstania Warszawskiego w Warszawie.

Placówki tego typu cieszą się zwykle dużym powodzeniem i są chętnie odwiedzane przez zwiedzających. Jest to niewątpliwie ich atutem - potrafią przyciągnąć uwagę, zaintrygować, „opowiadać” o historii w sposób zajmujący.

Ale istnieje też druga strona medalu. Pojawia się bowiem obawa, że niektóre z placówek tego typu, goniąc za coraz bardziej atrakcyjnymi sposobami prezentowania treści historycznych i z chęci przyciągnięcia publiczności, zdają się zatracać ich podstawowy sens. Muzeum może zatem przestać być placówką, bądź co bądź, jednak naukową, a stać się rodzajem centrum rozrywki, gdzie można wciskać guziczki, oglądać krótkie filmiki, odkopywać szkielety prehistorycznych stworzeń itp. Problemem jest też, czy muzea powinny wywoływać skrajne emocje, ekscytować tematami, które raczej winny budzić zadumę. W tej sytuacji niezbędna wydaje się, prócz umiejętności budowania ekspozycji, także refleksja teoretyczna dotycząca sposobu prezentowania treści historycznych ${ }^{12}$.

Przejdźmy do kolejnej kwestii, która potrafi wzbudzić duże emocje zarówno u profesjonalnych historyków, jak i szerokiej publiczności - chodzi tu o odbudowę, a często nawet budowę całkowicie od nowa, starych zabytków architektury, np. średniowiecznych murów obronnych, zamków itp. Nie mam na myśli sytuacji, kiedy odbudowa następuje wkrótce po zniszczeniu (tak jak się odbudowuje np. po wojnie, po przejściu kataklizmu itp.), ale o przypadki rekonstruowania budowli od lat, często od setek lat już nieistniejących. W tej chwili np. końca dobiega budowa zamku w Poznaniu na górze Przemysława.

Zwolennicy takiego budowania na nowo uważają, że da to lepszą możliwość poznania starej architektury, unaoczni, jak to naprawdę wyglądało, a przez to pełnić może funkcje poznawczo-edukacyjne. $Z$ kolei przeciwnicy zarzucają takim działaniom całkowitą sztuczność. Podkreślają, że owo „nowe-stare” wcale nie jest „stare”, ale tylko „nowe”, odarte z czegoś, co moglibyśmy nazwać - za Walterem Benjaminem - „aurą" miejsca, „aurą” oryginału ${ }^{13}$. Poza tym zwiedzający wcale

11 W. Kopczyński, Muzeum etnograficzne w Szwecji na przełomie XIX i XX wieku jako miejsce prezentacji dziedzictwa narodowego, „Zwierciadło Etnologiczne” 2012, nr 1, s. 94.

${ }^{12} \mathrm{Na}$ temat nowych muzeów zob. A. Ziębińska-Witek, Historia w muzeach. Studium ekspozycji Holokaustu, Lublin 2011; K. Szeska, Muzeum multimedialne - nowy sposób narracji o przeszłości, w: Media audiowizualne..., s. 259-273.

${ }_{13}$ W. Benjamin, Dzieło sztuki $w$ dobie reprodukcji technicznej, w: tenże, Anioł historii. Eseje, szkice, fragmenty, Poznań 1996, s. 201-239. 
nie chcą zapoznać się z dawnymi formami architektonicznymi, a podziwiać możliwości rekonstruowania.

W takim razie owe „nowe-stare” budowle (nierzadko z licznymi atrakcjami dla turystów) zdają się niekiedy kojarzyć z czymś na kształt Disneylandu: strzela się z łuków, pływa łódką $\mathrm{w}$ fosie, a także można za pomocą różnych przycisków włączać ekrany na ścianach „starego zamczyska”. Nie sposób nie postawić pytania o status takiej budowli: czy to prawdziwy zamek, rodzaj muzeum wizualnego, makieta, kopia oryginału?, czy tylko jest to naszym wyobrażeniem, może sumaryczną wiedzą o tym, jak budowano w średniowieczu? Są to kwestie warte przedyskutowania.

Następnym obszarem tematycznym historii wizualnej mogłyby się stać wszelkiego rodzaju inscenizacje i rekonstrukcje historyczne. I szerzej, wszelkiego typu widowiska, spektakle teatralne i działania plenerowe w jakikolwiek sposób ewokujące wydarzenia z przeszłości. Przykładem tu mogą być popularne dziś inscenizacje plenerowe konkretnych wydarzeń historycznych, np. bitew z licznych polskich zrywów powstańczych, ale także inscenizacje odtwarzające pewne elementy dawnego życia, zwyczaje, tradycje, np. turnieje rycerskie. Wielką popularnością cieszą się też różnego rodzaju parady, w czasie których ludzie poprzebierani w stroje wzorowane na starodawnych uświetniają uroczystości państwowe lub lokalne. Przykuwają one uwagę publiczności (często przybyłej z dziećmi) i bardzo mocno wpływają na wyobrażenie przeszłości.

Tego typu imprez jest niemało i zdają się zyskiwać na popularności. Szczególnie, że towarzyszą im często dodatkowe atrakcje - na straganach można kupić regionalne wyroby, w tym także spożywcze, pojawiają się kramy $\mathrm{z}$ antykami, niekiedy z militariami z myślą o kolekcjonerach.

Istnieją rozliczne sposoby urządzania takich inscenizacji. Niektóre - jak pisałam - dotyczą konkretnych wydarzeń historycznych. Te zwykle zachowują pewną spójność, nazwijmy to, stylistyczną. Osoby czynnie w nich uczestniczące przebrane są w stroje $\mathrm{z}$ określonej epoki i odtwarzają wydarzenia, które miały miejsce $\mathrm{w}$ danej epoce. Ale są też imprezy o odmiennym charakterze, które zawierają tylko elementy inscenizacji historycznej.

Historia wizualna niewątpliwie powinna zwrócić uwagę także na najnowsze media audiowizualne oraz technologie przenoszenia i gromadzenia informacji. Stajemy bowiem dziś wobec zupełnie nowej sytuacji i nieuchwytności treści niesionych przez Internet, brak tradycyjnych centrów nadawczych i istnienie wielu nadawców jednostkowych, wielka - praktycznie nieograniczona - przepustowość tego medium, interaktywność i zmienność stanowią swoiste wyzwanie. Jak badać treści niesione przez Internet, czy istnieje możliwość ich archiwizacji, czy stać się one mogą potencjalnym źródłem historycznym? A jeśli na to ostatnie pytanie odpowiedź jest pozytywna, to powstaje problem krytyki źródeł - ustalenie autorstwa, wiarygodności itp. $Z$ drugiej strony Internet daje niewątpliwie wielkie możliwości promocji wiedzy historycznej, wymiany informacji, ma walory edukacyjne. 
Te wszystkie cechy Internetu są zresztą doceniane, a sam mechanizm historycy już uczynili przedmiotem swoich badań ${ }^{14}$.

Warto tu zwrócić uwagę na portal internetowy historiaimedia, który prowadzą historycy młodego pokolenia. Mają oni świadomość, że rola mediów, a w szczególności Internetu, w kulturze historycznej będzie rosła. Interesują się oni Internetem, wszelkimi nowymi technologiami przekazywania i archiwizowania informacji, promocją „digital history”. Domniemywać należy, że znaczenie tego typu portali internetowych (historiaimedia, histmag) będzie wzrastać i że odgrywać one będą aktywną rolę w promowaniu Internetu jako nośnika treści historycznych.

Nie można zapomnieć również o portalach o charakterze hobbystycznym, które zwykle związane są z jakimś określonym tematem (np. historia rolnictwa), okresem historycznym lub zagadnieniem. Odrębny fenomen stanowią muzea internetowe. Są one bardzo zróżnicowane tematycznie: obok muzeum poświęconego Janowi Pawłowi II znaleźć można muzeum „Solidarności”, a nawet peerelowskich dobranocek. Prezentują one różny poziom wiedzy historycznej. Zdarzają się wśród nich jednak i takie, które upowszechniają materiały niedostępne w żadnym innym miejscu.

Osobnym działem - wymienionym wprawdzie na końcu, ale przez to wcale nie mniej ważnym - jest szeroko pojęta edukacja historyczna oparta na sztuce i mediach oraz materiałach audiowizualnych. Pisałam już o tym wcześniej, niemniej tutaj chciałabym zaznaczyć, że oprócz fotografii, filmu wykorzystać można do takiej edukacji także tradycyjne sztuki plastyczne ${ }^{15}$.

Historia wizualna jest subdyscypliną historii, która obejmuje swoim zasięgiem dość szerokie spektrum zagadnień, w odniesieniu do których trudno zastosować jedną metodę badawczą. Wymaga ona raczej podejścia multidyscyplinarnego.

Jeżeli fotografię i film (fabularny, dokumentalny, kronikę filmową, rejestrację spektaklu) potraktuje się jako źródła historyczne, nie powinno się rezygnować $\mathrm{z}$ tradycyjnych metod badawczych historii, tzn. $\mathrm{z}$ analizy źródeł, o czym już pisałam. Jednak po ustaleniu autentyczności, autorstwa i wiarygodności danego materiału (audio)wizualnego przechodzi się do samej jego analizy. Jest to właśnie moment, kiedy skorzystać można $\mathrm{z}$ dorobku innych dyscyplin naukowych. Mamy tu do czynienia nie z tekstem pisanym, ale obrazem i ruchem (film niemy) bądź ruchem, obrazem - czarnobiałym lub kolorowym - i dźwiękiem.

${ }^{14}$ Zob. np. M. Szczurowski, Nowe nośniki wiedzy o przeszłości? Rzecz o komunikatorach internetowych i poczcie elektronicznej, w: Media audiowizualne..., s. 53-88; D.J. Stanley, Computer, Visualization and History. How New Technology will Transform our Understanding of the Past, New York 2003; M. Wilkowski, Wprowadzenie do historii cyfrowej, Gdańsk 2013.

15 Zob. J. Budzińska, Źródło ikonograficzne w szkolnej edukacji historycznej na przykładzie zbiorów muzeów wielkopolskich, Poznań 2014. 
Najpierw potrzebne będzie ustalenie pewnych cech formalnych, co w przypadku materiałów filmowych niekiedy ma znaczenie pierwszorzędne. A więc z jakiego rodzaju materiałem mamy do czynienia (fabuła, dokument, kronika, materiał informacyjny itd.). W dalszej kolejności - w przypadku filmu dokumentalnego i jeszcze bardziej fabularnego - istotne jest określenie jednostki genologicznej. Przynależność gatunkowa danego filmu - a co za tym idzie cały zestaw określonych środków wyrazu - niekiedy może być bardzo ważne ${ }^{16}$. W dalszym ciągu analizy należałoby zastanowić się nad zawartością treściową i spróbować uchwycić jego znaczenie. W odniesieniu do przekazów filmowych można by wtedy wyróżnić cztery metody badawcze. 1) Metodę analizy kompozycyjnej biorącej pod uwagę filmowe środki wyrazu, takie jak montaż, dźwięk, kompozycję obrazu, scenografię, kolorystykę i oświetlenie. 2) Metodę analizy semiologicznej, traktującej przekaz filmowy (także spektakl, ekspozycję muzealną itd.) jako rodzaj znaku kulturowego; wskazuje to na sposób konstruowania znaczeń w określonych kulturach. 3) Metodę analizy dyskursywno-tekstologicznej. Na jej gruncie bada się, w jaki sposób budowane są przedstawienia przeszłości w kontekście społecznym; wskazuje to na znaczeniotwórczą rolę przedstawień wizualnych. 4) Metoda analizy mediów, gdzie zwraca się uwagę na rodzaj medium, za pomocą którego przenoszone są określone treści.

Powyższe dywagacje dotyczą tylko jednej z dziedzin historii wizualnej, zajmującej się sposobami wykorzystania materiałów (audio)wizualnych w charakterze źródła historycznego. I to nie wszelkich tego rodzaju materiałów, a tylko filmu. Zostały tu zarysowane pewne podejścia do tak potraktowanych materiałów (audio)wizualnych, które jednakże domagają się wypróbowania na konkretnym materiałach, użytych celem poznania interesującej badacza rzeczywistości. Oprócz filmu przydatne mogą się okazać inne obrazy - nieruchome i pozbawione fonii. Wymagają jednakże nieco innych zabiegów.

Historia wizualna interesuje się także innymi sprawami: jak należy wykorzystać te wszystkie obrazy w procesie przekazywania wiedzy o przeszłości następującym $\mathrm{w}$ trakcie szkolnej edukacji oraz poza nią. A także jak się to w praktyce robi. Analizować można więc mnóstwo przedstawień wizualnych: bitwy odgrywane przez pasjonatów rekonstrukcji historycznych, ekspozycje w muzeach multimedialnych czy gry historyczne. Analiza zaś może doprowadzić do rozmaitych spostrzeżeń. Nie tylko dotyczących stopnia zgodności różnych wizualizacji historycznych z ustaleniami badaczy dziejów, ale i świadomości historycznej społeczeństwa w danym okresie, a w dalszej kolejności jego współczesnej kondycji.

${ }^{16}$ M. Przylipiak, O gatunkach filmowych, w: Od fantastyki do komiksu. W kręu gatunków filmowych, red. K. Sobotka, Łódź 1993, s. 5-35; K. Loska, Kilka uwag o problemie gatunków filmowych, w: Wokót kina gatunków, red. K. Loska, Kraków 2001, s. 7-10. 
Zatem historia wizualna jest wciąż humanistyką snującą rozważania o przeszłości, tyle tylko, że w oparciu o materiał dotąd wcale lub bardzo rzadko wykorzystywany. Jako taka zdaje mieć przed sobą szerokie perspektywy, ponieważ znaczenie sfery wizualnej nieustannie wzrasta i przybywa pokoleń, które o przeszłości chcą nie tylko czytać, ale też ją zobaczyć.

\section{Bibliografia}

K. Ashenburg, Historia brudu, tłum. A. Górska, Warszawa 2010

W. Benjamin, Dzieło sztuki $w$ dobie reprodukcji technicznej, w: tenże, Anioł historii. Eseje, szkice, fragmenty, Poznań 1996, s. 201-239

J. Budzińska, Źródło ikonograficzne w szkolnej edukacji historycznej na przykładzie zbiorów muzeów wielkopolskich, Poznań 2014

O.V. Burton, American Digital History, „Social Science Computer Review” 25, 2005, nr 2, s. 206-220

H. Innis, Empire and Communication, Oxford 1950

K. Loska, Kilka uwag o problemie gatunków filmowych, w: Wokót kina gatunków, red. K. Loska, Kraków 2001, s. 7-10

H. Karczowa, Rozwój form kancelaryjnych i wspótczesne rodzaje dokumentów archiwalnych. Dokumentacja wizualna i audialna (fotografia, film, nagrania), Torun 1979

W. Kopczyński, Muzeum etnograficzne w Szwecji na przełomie XIX $i$ XX wieku jako miejsce prezentacji dziedzictwa narodowego, „Zwierciadło Etnologiczne” 2012, nr 1, s. 69-100

I. Mamczak-Gadkowska, Fotografie i filmy $w$ archiwach, w: Media audiowizualne w warsztacie histo$r y k a$, red. D. Skotarczak, Poznań 2008, s. 89-105

B. Matuszewski, Nowe źródło historii. Ożywiona fotografia: czym jest, czym być powinna, Warszawa 1995

W. Olejniczak, Film fabularny jako źródło historyczne, w: Media audiowizualne w warsztacie historyka, red. D. Skotarczak, Poznań 2008, s. 25-52

W.J. Ong, Pismo a struktura świadomości, tłum. M. Pęczak, w: Wiedza o kulturze, cz. 2: Słowo w kulturze. Zagadnienia i wybór tekstów, oprac. M. Boni, G. Godlewski, A. Mencwel, Warszawa 1991, s. $127-144$

E. Podgórska, Archiwizacja fotografii, w: Poradnik dla archiwisty instytucji polskich na obczyźnie, red. J. Krochmal, Warszawa 2006, s. 73-84

M. Przylipiak, O gatunkach filmowych, w: Od fantastyki do komiksu. W kręgu gatunków filmowych, red. K. Sobotka, Łódź 1993, s. 5-35

W.K. Roman, Naukowa informacja archiwalna o materiałach audiowizualnych $i$ jej rola $w$ badaniach historycznych, w: Media audiowizualne w warsztacie historyka, red. D. Skotarczak, Poznań 2008, s. $107-128$

D. Skotarczak, Film fabularny jako źródło do badań historii społecznej PRL, w: Dokument filmowy i telewizyjny, red. M. Szczurowski, Toruń 2004, s. 156-169

D. Skotarczak, Historia wizualna. Założenia teoretyczne i zakres badawczy, w: Historia w kulturze współczesnej. Niekonwencjonalne podejście do przeszłości, red. P. Witek, M. Mazur, E. Solska, Lublin 2011, s. 87-94

D. Skotarczak, Historia wizualna, Poznań 2012

D. Skotarczak, Kino PRL-u w materiałach dydaktycznych MEN, w: Uwikłania historiografii. Między ideologizacja dziejów a obiektywizmem poznawczym, red. T. Błaszczyk, K. Brzechczyn, D. Ciunajcis, M. Kierzkowski, Poznań 2011 (Studia i Materiały Poznańskiego IPN, 18), s. 177-184

D. Skotarczak, Obraz społeczeństwa PRL w komedii filmowej, Poznań 2004 
D. Skotarczak, Projekt historii wizualnej, „Slavia Occidentalis” 2011, nr 68, s. 173-177

D. Skotarczak, Wśród filmowych źródeł do historii Polski Ludowej, „Porównania. Czasopismo poświęcone zagadnieniom komparatystyki literackiej oraz studiom interdyscyplinarnym" 2010, nr 7, s. 141-150

J. Stanley, Computer, Visualization and History. How New Technology will Transform our Understanding of the Past, New York 2003

J. Szacki, Tradycja. Przeglad problematyki, Warszawa 1973

M. Szczurowski, Nowe nośniki wiedzy o przeszłości? Rzecz o komunikatorach internetowych i poczcie elektronicznej, w: Media audiowizualne w warsztacie historyka, red. D. Skotarczak, Poznań 2008, s. $53-88$

K. Szeska, Muzeum multimedialne - nowy sposób narracji o przeszłości, w: Media audiowizualne $w$ warsztacie historyka, red. D. Skotarczak, Poznań 2008, s. 259-273

M. Wilkowski, Wprowadzenie do historii cyfrowej, Gdańsk 2013

P. Witek, Andrzej Wajda jako historyk. Metodologiczne studium z historii wizualnej, Lublin 2016

P. Witek, Kultura, film, historia. Metodologiczne problemy doświadczenia audiowizualnego, Lublin 2005

A. Ziębińska-Witek, Historia w muzeach. Studium ekspozycji Holokaustu, Lublin 2011

\section{Some remarks on visual history}

In the course of its development historiography has faced all kinds of challenges typical of a given stage in the development of civilisation. Visual representations come into the category of such challenges. An incresingly acknowledged subdiscipline of history, visual history sets itself the task of studying all kinds of audiovisual representations of the past, including the artistic ones such as film, photography and art. It is informed by the assumption that the increasing role of audiovisual ways of representing reality, including the past reality, makes it necessary for historiography to modify the fundamental presuppositions on which it is based, without, however, abandoning the traditional goals it is called upon to pursue. Visual history insists on the use of film or photographs as historical sources. This in turn requires the elaboration of specific methods of dealing with such sources, which are so significantly different from those usually made use of by historians. The discipline in question also takes an interest in the use of audiovisual means in historical education and in the popularisation of historical knowledge. History's shift in the direction of audiovisual media inspires methodological discussions that contribute to the elaboration of both practical and theoretical solutions to a variety of problems this shift creates.

Dorota Skotarczak - prof. w Instytucie Historii Uniwersytetu Adama Mickiewicza, kierownik Pracowni Historii Wizualnej. Zainteresowania naukowe: historia kultury, historia wizualna, wizualne metody w naukach historycznych. Ostatnio opublikowała pracę: Historia wizualna, Poznań 2012. E-mail: skot@amu.edu.pl. 